dollars. In addition to grants to various national emergency organizations, the Corporation voted 75,000 dollars to the Carnegie Endowment for International Peace for its educational work in the United States, 40,000 dollars to the Council of Foreign Relations for its research and publication programme and programme of regional committees, 34,000 dollars to the Institute of Pacific Relations and 10,000 dollars to the Foreign Policy Association.

The most ambitious single Corporation project concerning the Negro has been the comprehensive study of the Negro in America conducted by a staff of research specialists directed by Dr. Gunnar Myrdal, which was published in two volumes in January 1944 under the title "An American Dilemma : The Negro Problem and Modern Democracy". The Corporation is endeavouring to regain and maintain flexibility of action from year to year in regard to the use of annual income, and the trustees are studying carefully what particular interests in the crucial times to come may best constitute an effective programme for the Corporation. The report of the secretary also includes a list of useful publications with the issue of which the Corporation has been concerned.

\section{THE COD}

$\mathrm{A}$ $\mathrm{N}$ important and detailed account of the biology and economy of the cod in the Newfoundland area has now become available*, based mainly on tagging experiments during 1931-35, both in inshore and in deep waters. The fishing industry in these regions has tended to lag behind those of other countries, not on account of lack of fish but because of the geographical position of Newfoundland, its small population and the absence of international trading facilities. With Norway and Iceland it is one of the three great centres of cod stocks, and it has also many other valuable fish.

The vast area of Grand Bank is the outstanding important portion of the Newfoundland area and is the key area for study. It should probably be regarded as containing the parent cod stocks with which many subsidiary stocks, including those found inshore, must be correlated. The study of the inshore cod should therefore on no account be separated from that of the cod on the banks, especially Grand Bank, and the deep-sea fishing should certainly be increased and not reduced, as the reservoir of fishes is on the banks. It is essential that both the inshore and bank fisheries should be intensively developed.

Reference for comparison is made to previous tagging experiments in the north-western Atlantic, Greenland and Iceland, the Faroe Channel and the north-eastern Atlantic. From these it appears that the cod (especially young cod) are comparatively circumscribed in their movements, the larger proportion of recaptures being made in or near the point of tagging. A few carry on extended migrations, and for spawning purposes there can be what amounts to mass migration from one region to another, the migration being necessary probably where good foeding and spawning conditions do not occur in the same region. The evidence supports the general hypothesis of the existence of local races of cod, most

- Newfoundland Gov. Research Bull. No. 14: A Biological and Economic Study of the Cod (Gadus callarias L.) in the Newfoundland Area including Labrador. By Dr. Harold Thompson. Pp. 160. (St. John's: Department of Natural Resources, 1943.) of which, in any event in the early years of life, remain within a region where a specific range of hydrographic and feeding conditions prevails, and in these there are characteristic and recognizable biological features, such as average number of vertebræ, rate of growth and fluctuations in good, moderate and poor years of hatching and survival of fry.

With regard to the Newfoundland tagging experiments, the main object of which was to obtain direct evidence of migrations, it was found that those tagged on the banks were much larger than those tagged elsewhere, the latter being mostly immature fish; 91.2 per cent of the inshore cod tagged were recaptured locally within 100 miles (and more than half of these within 10 miles), and only 8.8 per cent travelled distances of upwards of 100 miles. Only 1.5 per cent travelled more than 250 miles, a distance which might or might not take the cod into a zone of markedly different hydrographical conditions. With the bank cod the results were somewhat similar, but only 68.9 per cent were recaptured within 100 miles, and $31 \cdot 1$ per cent carried out migrations of more than 100 miles. Only $6 \cdot 8$ per cent exceeded 250 miles. Thus the bank cod carried on rather more extensive migrations than those from the inshore.

The fish up to about three years old are practically stationary, and up to the age of six or seven years, or even more, the average movement from the location would probably not exceed 200 miles. Thus there is every reason to believe that races of cod can occur. After maturity is reached, there appear to be increased migrations and intermingling. The maximum distance travelled by any recaptured cod was 560 miles, from Fortune, in the south of Newfoundland, to White Bay, in the north-east.

From the analysis of results of counts of vertebræ, and of first-year circuli in the fish scale, it is possible to recognize two main stocks: those growing to maturity in cold water (arctic type) and those in warmer ocean water (bank type) respectively. Mixing of these also takes place to a certain extent. The parent stock is probably that of the Grand Bank.

The majority of Newfoundland cod attain first maturity between the sixth and ninth year of life, at a size of $60-80 \mathrm{~cm}$. In this they resemble Iceland and Norwegian cod rather than those from the North Sea, where maturity occurs at an earlier age than the above. Most spawning occurs in spring, but the season may extend from March to October. It is later in the north than in the south. The distribution of eggs and fry varies according to the type of season-whether or not the arctic current is of normal, or of greater or less than normal strength. Eggs and fry occur chiefty off the east coast of Labrador and Newfoundland and on the banks, the centre of density of distribution being rather more northerly in warmer years, and more southerly in colder years.

The fishery in general is most successful in colder rather than warmer years, although cod in moré southerly regions are conditioned to water of higher temperatures than are cod of more northerly regions. In the latter, large catches are made in water of temperature $0^{\circ} \mathrm{C}$. and even lower. The optimum temperature for large catches varies according to the region. It would be of advantage if information on prevailing and probable temperature conditions were made available to fishermen.

There is no sign of overfishing on the Grand Bank, which is probably capable of producing a higher yield. It is through the moderate development of trawling that progress is likely to be made. 